\title{
RECONSTRUCTION OF EXECUTIVE AND LEGISLATIVE AUTHORITIES TO MAKE A GOOD GOVERNANCE BASED ON WELFARE VALUES
}

\author{
Mohamad Khamim \\ thewanker47@yahoo.co.id \\ Universitas Pancasakti Tegal
}

\begin{abstract}
The executive and legislative powers of good governance based on welfare values imply that the executive and legislative bodies as the state organizers and the bearers of the mandate to manage public affairs should prioritize the general interests and safeguard the public good over many individual and group interests. The executive and legislative authorities in realizing good governance have not worked well due to the practice of extraterrestrial partnership relations, especially in terms of APBD (Regional Budget) arrangements that seem to promote personal or group interests. The role of function is large enough to cause conflict between the executive and legislative (local government), especially the head of the region.
\end{abstract}

\section{Keywords : Authority, Good Governance, and Welfare}

\section{A. INTRODUCTION}

The development of laws and regulations governing the system of local governance since the founding of the Unitary State of the Republic of Indonesia, as well as the demands of political change in the regions has prompted the central government to dilute the centralism of power that has long been in the center of government. The legislative tendency of the region acts beyond its rights and authority by intervening in the authority of the regional executive, whereas the regional executive tends to use the old dogma which wants to remain in power thoroughly and dominantly. This allows for conflict and unharmonious relationships between the executive and legislature in a local government.

A representative institution must be able to optimize its political function independently so as to position itself neutrally in assessing the 
government and its people. In essence, regional autonomy is the right to organize self-government based on the aspirations and needs of the community without interference from the upper-level government.

This means that regional autonomy provides an opportunity for the community, including apparatus and people's representatives to participate in planning and implementing policies independently without the need for central considerations as long as it is still within the regulatory corridor.

The principle of local governance is the principle of autonomy and duty of assistance. In accordance with the explanation in the constitution by Bagir Manan explained in a number of short articles that decentralization and deconcentration in the perspective of constitutional law is only a way of organizing government by the central government in the region. That is, the implementation of local government can be done by decentralization or deconcentration. ${ }^{1}$

In the new paradigm of regional autonomy allows the implementation of control over local government to be effective. Here the DPRD is expected to be able to play its role and function optimally in the process of efficient, effective, clean, authoritative and efficient regional government administration, so that people can enjoy the reality of a decent life. ${ }^{2}$

In essence, the main function of the legislative (DPR/DPRD) is the function of oversight and legislation. An additional function that is closely related to both functions is the budget function. In the implementation of these two main functions in the field of oversight and legislation, this legislative position is very strong. Instruments that can be used by the

\footnotetext{
${ }^{1}$ Bagir Manan, Menyongsong Fajar Otonomi Daerah, PSH Fak. Hukum UII, Yogyakarta, 2001, page. 11 .

2 Bambang Yudoyono, Kajian Awal Birokrasi Pemerintahan dan Politik Orde Baru, Tasrif Watampone, Jakarta, 2001, page. 97. 
parliament to effectively oversee the functioning of the government are (a) budgetary rights, (b) interpellation rights, (c) right of inquiry, (d) right of resolution, (e) or the right to elect a certain candidate. In addition to institutional rights, each individual legislative member is also guaranteed the right to ask questions and propose opinions and other rights such as immunity rights and protocol rights. All rights are important as instruments that can be used in carrying out the function of political oversight of good governance based on the value of welfare.

Based on the background for the above research, the writer formulated several problems as follows:

1. Why do the executive and legislative authorities in realizing good governance in the perspective of Law no. 23 Year 2014 on Local Government has not gone well?

2. What are the weaknesses of the executive and legislative authorities in realizing good governance today?

3. How does the reconstruction of executive and legislative authorities in realizing good governance based on welfare values?

\section{B. RESEARCH METHODS}

This research was conducted by using normative judicial approach, because library material was used as main material that is primary material consisting of basic norm or rule, basic rule or regulation, and also regulation. In addition, secondary legal materials were used as secondary data which includes primary, secondary, and tertiary legal materials.

This research is analytical descriptive because it aims to give description about facts along with accurate analysis. Data analysis was done by descriptive and explanatory. The point is that the researcher described the facts and data obtained from the research. Then it was followed up by explaining the data and facts that have been described. 


\section{RESULTS AND DISCUSSION}

1. The executive and legislative authorities in realizing a good government in the perspective of Law no. 23 of 2014 on Regional Government has not gone well;

The function of legislation (the formation of Perda/regional regulation) is the main function of DPRD as the regional legislative body. Marbun argued that "the function of making the law is the main and original function of the Regional People's Legislative Assembly as a legislative body. Through this function, DPRD (Regional House of Representative) can show the color, character and quality, both materially and functionally"3. This legislative function is attached to the DPRD as it is a representative body of the people.

DPRD is a legislative institution in the region. Strong argues that the legislature is the power of the government which deals with the making of the law, in so far as the law requires statutory force. This also remembers that the legislature in Indonesia is an institution that has a function as a representative institution of the people. ${ }^{4}$

The position of the Regional People's Legislative Assembly as the regional government organizer together with the regional government places the DPRD under the control of the Central Government through the Ministry of Home Affairs due to the local government administration under the Ministry of Home Affairs. The consequences of this DPRD position caused various regulations to be regulated in the Central Government's legal products such as Government Regulation, Permendagri, and Circular Letter. As a result of the DPRD as an element of the implementation of the regional administration, the DPRD is more subject to the Minister of Home

\footnotetext{
${ }^{3}$ B.N. Marbun, DPRD Pertumbuhan, Masalah dan Masa Depannya, Ghalia Indonesia, Jakarta, 1983, page. 162.

${ }^{4}$ C.F Strong, Modern Political Constitution: An Introduction To The Comparative Study Of History And Exising From, Sidwick And Jackson, London, 1975, page. 8. 
Affairs, subject to Government Regulation than the constituents it represents-the people. ${ }^{5}$

The executive and legislative authorities in realizing a good government in the perspective of Law no. 23 of 2014 has not gone well. Implementation of local government can be seen from the juridical and philosophical differences. The juridical distinction is contained in the form of articles that regulate matters not regulated in the preceding legislation. While the philosophical differences seen from the meaning and orientation that is explicitly contained in the articles that were not previously regulated in the previous law. The difference is juridical, very visible in the absence of articles that regulate the implementation of regional head elections. The subject of regional election has been regulated in Law no. 23 year 2014. The main reason stated in the academic draft of RUU Pilkada (Regional Election) is meant for the law both local government and local elections can run maximally in accordance with their respective central issues. In addition, in the separation of local government and regional elections are intended to reinforce the position and differentiation of the governor and the mayor/regent. This is because the governor is elected through a direct election mechanism. However, unilaterally it is coopted by placing the governor as the representative of the central government. In academic perspective the position of governor can be categorized as "intermediate unit". The hallmark of the "intermediate unit" in its administration deals with the de-concentration of decentralization. Thus, the governor elected directly by the people, his authority is "castrated" because of his double status which is also a representative of the central government. In contrast to the mayors and district heads who are both elected by the people but their status as autonomous regions that put forward the principle or principle of decentralization. This is where

\footnotetext{
5 http://www.parliament.uk/factsheets, Undang-Undang Susduk: Pintu Masuk Penguatan Lembaga Perwakilan.
} 
the urgency of separating local governance and election of elections into two different laws.

In Law no. 23 Year 2014, government affairs are divided into absolute matters organized by the central government, the affairs of the constituent governments that are shared between the central government, provincial and district/municipal governments. Therefore, in Law no. 23 Year 2014, government affairs implemented by the local government is divided into two types. It is included in Article 9 paragraph (1) that government affairs consist of absolute government affairs, concurrent government affairs, and general government affairs, (2) absolute government affairs as referred to in paragraph (1) shall be government affairs entirely under the authority of the central government (3) concurrent government affairs as referred to in paragraph (1) shall be government affairs divided between central and provincial and districts/municipal governments, (4) concurrent government affairs assigned to regions shall be the basis for the implementation of regional autonomy, 5) general government affairs as referred to in paragraph (1) shall be government affairs authorized by the president as head of government.

The spirit of Law no. 23 of 2014 is to maximize the role of local governments that are able to carry out the authority oriented basic services not just power. Under these conditions, inevitably, the participation of the public is in terms of supervision of government-based public service provision. The form of manifestation of the juridical renewal spirit is set forth in Chapter XIII on Public Service. This chapter discusses the efforts of local governments in meeting the needs of society as a form of public services. Thus, the public is able to provide feedback on public services provided by the local government. Therefore, the Law also regulates Community Participation in Chapter XIV. The existence of Law 
no. 23 of 2014 is expected to improve the system of regional governance. In addition, the change orientation from mere power to public services should be able to encourage the improvement of people's welfare in the regions.

2. The weaknesses of the executive and legislative authorities in realizing good governance at present;

The weaknesses of the executive and legislative authorities in realizing good governance today are the occurrence of excessive partnership engagement practices, especially in the case of APBD (Regional Budget) arrangements that seem to promote personal or group interests should be avoided. There is hope with the Act of 23 Year 2014 developed a partnership attitude guarded by law enforcement against the practices of corruption in the region.

The dysfunction and stagnation of local government and DPRD (Regional House of Representative) is one of the causes of the failure of the implementation of regional autonomy at the expense of the basic rights of the people. The failure of regional autonomy to fulfill people's basic rights is a serious matter. Much work remains to be done to ensure that political instruments such as Pilkada (Regional Election) are able to produce effective, credible and responsible local governments, and are relevant to the communities and regions concerned. In the meantime, local governments that are still in office also need to take initiative and strategic steps in utilizing its authority to run development programs in the regions effectively and optimally.

Some indications are not successful implementation and less running Law no. 23 of 2014 are as follows:

a. There was a seizure of positions among politicians from the Political Parties and the bureaucrats who had pursued a career with 
education and with long hours of experience to occupy executive positions. In fact, there is money politics. However, according to the initial shouts of reform, KKN (Corruption, Collusion and Nepotism) should be eroded, especially the "bribery" in terms of nomination of regional head and his deputy. Until now there are cases of money politics which has not been solved juridically;

b. Not all legislative and executive parties in the District and Municipal areas are considered "ready" in the sense of mastering the understanding to apply the Act, with the same perception;

c. There is uncertainty over whether or not the preparation of the District Development Program (Propeda) of the Regency should be prepared in accordance with the Provincial Propeda (including its Strategic Plan), and vice versa whether the pro-provincial government still has the authority to provide some kind of strategic direction to the district and city. Even if it does not recognize the need for subordination, does it no longer need co-ordination, as one of the functions of management;

d. Such an attitude is so extreme that districts and municipalities consider no administrative-functional and functional linkages at all with the province, and some KDH have been in direct contact with the central government without "notifying or giving any news" to the provincial KDH governor;

e. There is a tendency for districts to dredge as much of PAD sources as if the interests of community welfare are dubbed, and it is not guaranteed that these levies will feed back, melting process as a cost to overcome public welfare;

f. There appears to be a tendency to overlap territory between the districts with an overwhelming autonomous spirit and assume that there should be no more central intervention in the case despite 
claiming that the country is a unitary state. In practice and development in the regions, it emerges that the rulers as local government organizers have become a kind of "little kings" claiming that there is no coordination and control of the provinces/governor to District/regents and municipalities/Mayor.

3. Reconstruction of executive and legislative authority in realizing good governance with welfare-based values.

Reconstruction of executive and legislative authorities in good governance based on welfare values is done by efficiency and effectiveness of executive and legislative authorities capable of improving public service and welfare.

The reconstruction of the law by making changes to Article 63 paragraph (1), Article 65 paragraph (1) letter (f), Article 66 paragraph (3) and the addition of paragraph (4), Article 88 of Law no. 23 of 2014 as follows:

a. Article 63 (after reconstruction):

(1) The regional head as referred to in Article 59 paragraph (1) shall be assisted by the deputy regional head;

(2) The deputy head of the region as referred to in paragraph (1) for the province shall be called the vice-governor, for the district referred to the vice-regent, and for urban areas the representative of the mayor.

b. Article 65 (after reconstruction):

The regional head has the duty:

a. To lead the implementation of government affairs which become the regional authority based on the provisions of laws and regulations stipulated in parliament;

b. To maintain public order and peace; 
c. To prepare and submit a draft of Perda on RPJPD and draft local regulation on RPJMD to DPRD to be discussed with DPRD, and to formulate and establish RKPD;

d. To prepare and submit draft laws on APBDs, draft local regulations on APBD changes, and draft local regulations on accountability of APBD implementation to DPRDs to be discussed together;

e. To represent its territory within and outside the court, and may appoint legal representatives to represent it in accordance with the provisions of legislation;

f. Deleted;

g. To carry out other duties in accordance with the provisions of legislation.

c. Article 66 (after reconstruction)

(1) The deputy regional head shall have the following duties:

a. Assisting regional heads in:

1. Leading the implementation of government affairs that become regional authorities;

2. Coordinating the activities of the regional apparatus and to follow up the reports and / or findings of the supervisory apparatus;

3. Monitoring and evaluating the implementation of regional government exercised by the provincial apparatus for the vicegovernor; and

4. Monitoring and evaluating the administration of the government carried out by the regional apparatus of the District/city, village for the vice regent/mayor.

b. Providing advice and consideration to the regional head in the implementation of regional government; 
c. Carrying out the duties and authorities of the regional head if the head of the region undergo a period of detention or temporarily absent; and

d. Carrying out other duties in accordance with the provisions of legislation.

(2) In addition to perform the duties referred to in paragraph (1) the deputy regional head shall carry out other duties and obligations of the other government given by the regional head determined by the decision of the regional head;

(3) In performing the duties referred to in paragraphs (1) and (2), the deputy regional head shall sign an integrity pact and shall be accountable to the regional head;

(4) The deputy head of the region shall perform the duties with the regional head until the end of the term of office.

d. Article 88 (after reconstruction):

(1) In the event that the filling of the office of governor as meant in Article 87 paragraph (1) has not been done, the deputy governor shall perform the day-to-day task of the governor until the appointment of the deputy governor as governor;

(2) In the event that the filling of regent/mayoral office as referred to in Article 87 paragraph (2) has not been done, the vice regent/vice mayor shall perform the day-to-day task of the regent/mayor until the vice regent/mayor is appointed as regent/mayor.

Provincial and district/municipal government administrators consist of regional head and DPRD assisted by regional apparatus. On the basis of the new function of the DPRD, the DPRD performs the functions of regulation, budget and supervision on the implementation of local government in the execution of its duties and responsibilities. With the 
election of the regional head by the DPRD allows the head of the region tend to ignore the public. In the new order era until the reformation, the Indonesian people assume the head of the region (regents, mayors, and governors) never take care of the public interest. The heads of the regions only take care of the interests of the DPRD who have chosen them. DPRDs can be authoritarian.

In every year, there is a performance responsibility of the regional head to the DPRD. If a council member refuses, the regional head is immediately dismissed. In the new order era, the DPRD became the most powerful party. To avoid heads of regions that tends to ignore the public, to take care of their own interests when compared with the public interest/people, elections by the people's most correct and the local parliament in charge of overseeing the government because DPRD is also elected by the people. So that Article 101 paragraph (1) letter $d$ and addition d1, and Article 154 paragraph (1) letter $d$ and addition of letter d1 Act no. 23 of 2014 as follows:

a. Article 101 (after reconstruction):

Provincial DPRD has the duty and authority to:

a. Establish Provincial law with the governor;

b. Discuss and give approval of Provincial Draft Regulation concerning Provincial APBD proposed by the governor;

c. Implement supervision on the implementation of provincial regulations and provincial APBD;

d. Deleted;

d1. To elect the governor and the deputy governor in the case of vacancy to continue the remaining term of office;

e. Propose the appointment and dismissal of the governor to the president through the minister to obtain the appointment of appointments and dismissals; 
f. Provide opinions and considerations to provincial governments on international agreement plans in the provinces;

g. Approve the plans of inter-national cooperation undertaken by the provincial government;

h. Request a report on the accountability of the governor in the implementation of the provincial government;

i. Approve the plan of cooperation with other regions or with third parties that burden the people and the provinces; and

j. Carry out other duties and authorities stipulated in the provisions of legislation.

b. Article 154 (after reconstruction):

Regency/Municipal DPRD has the duty and authority to:

a. Establish district/municipal regulation with regent/mayor;

b. Discuss and grant approval of local regulation concerning district/municipal APBD submitted by regents/mayors;

c. Implement supervision on the implementation of local regulations and district/municipal APBD;

d. Deleted;

d1. Choose regents and vice regents and mayors and deputy mayors in case of vacancy to continue the remaining term of office;

e. Propose the appointment and dismissal of the regent/mayor to the minister through the governor as the representative of the central government for the approval of appointment and dismissal;

f. Provide opinions and considerations to district/municipal governments on plans for inter-national agreements in the regions;

g. Approve the plans of international cooperation undertaken by district/municipal governments; 
h. Request report on accountability of regent/mayor in the administration of district/municipal government;

i. To approve cooperation plans with other regions or with third parties who burden communities and regions;

j. Carry out other duties and authorities stipulated in the provisions of legislation.

\section{CONCLUSION}

\section{Summary}

a. The executive and legislative authorities in realizing good government in the perspective of Law Number 23 Year 2014 have not gone well because they still prioritize political interests, KKN (Corruption, Collusion, Nepotism), work out of authority, lack of integrity and transparency and quality of service to a deteriorating society. These are some of the problems that make good governance unachievable. Persons of government organizations who should be role models of the people who stumble over legal issues. The existence of good governance or often called good governance which has been hailed the facts at this time is still a dream and is merely a jargon. Revolution in every field must be done because every product produced only accommodate the interests of political parties, factions and groups of people;

b. The weaknesses of the executive and legislative authorities in realizing good governance today are the occurrence of excessive partnership practices, especially in the case of APBD arrangements that are impressed to promote personal or group interests. Some indications are not successful implementation and less running Law no. (Ii) not all legislative and executive parties in the districts and municipalities are considered "ready" to be "politicians" or 
"politicians" in the sense of mastering the understanding to apply the law, with the same dimensions, (iii) there is uncertainty about whether or not the preparation of the District Development Program (Propeda) of the Regency should be prepared in accordance with the Provincial Propeda (including its Strategic Plan), and vice versa; (iv) there is such an extreme attitude that districts and municipalities consider no administrative and functional relationship at all with the province, and some $\mathrm{KDH}$ have been in direct contact with the central government without "noticing or giving news" to the provincial governor of $\mathrm{KDH},(\mathrm{v})$ there is a tendency of kabupa-ten to extract as much of the PAD source as if the interest of the people's welfare is dubbed, and not necessarily guaranteed that the feedback, melting process as a cost disruption of public welfare, (vi) there is a tendency for the exclusion of power domains among districts with an overwhelming autonomy spirit and assumes that there should be no more central interference with their cases despite claiming that this country (still) a unitary state;

c. Reconstruction of executive and legislative authorities in good welfare-based government with the efficiency and effectiveness of executive and legislative authorities capable of improving public service and people's welfare. The reconstruction of the law by the amendment of Article 63 paragraph (1), Article 65 paragraph (1) letter ( $\mathrm{f}$ ), Article 66 paragraph (3) and the addition of paragraph (4), Article 88 of Law no. 23 of 2014.

\section{Suggestions}

1. The Government and the People's Legislative Assembly need to make amendments to Law no. 23 of 2014, especially Article 63, 
Article 65, Article 66, Article 68, Article 88, Article 101 and Article 154;

2. In the context of institutional relationships, it is the duty and function of the DPRD to oversee local government. Here the parameters are the understanding, knowledge and commitment of the DPRD (Regional People's Representative Assembly) to be guaranteed. That is, if all qualifications to oversee the DPRD have been fulfilled, it is very possible the DPRD can contribute to realize clean and authoritative government;

3. For law enforcement, the DPRD's members who are proven to be involved in KKN should be punished as severely as possible by law and justice. If the law can be enforced, it becomes a lesson for the next DPRD to be more careful in acting, acting and so on. In the future, there needs to be a more stringent screening and political recruitment of candidates for Regional People's Representative Assembly.

\section{References}

\section{A. Books}

B.N. Marbun, DPRD Pertumbuhan, Masalah dan Masa Depannya, Ghalia Indonesia, Jakarta, 1983.

Bagir Manan, Menyongsong Fajar Otonomi Daerah, PSH Fak. Hukum UII, Yogyakarta, 2001.

Bambang Yudoyono, Kajian Awal Birokrasi Pemerintahan dan Politik Orde Baru, Tasrif Watampone, Jakarta, 2001. 
C.F Strong, Modern Political Constitution: An Introduction To The Comparative Study Of History And Exising From, Sidwick And Jackson, London, 1975.

B. Internet :

http://www.parliament.uk/factsheets, Undang-Undang Susduk: Pintu Masuk Penguatan Lembaga Perwakilan. 